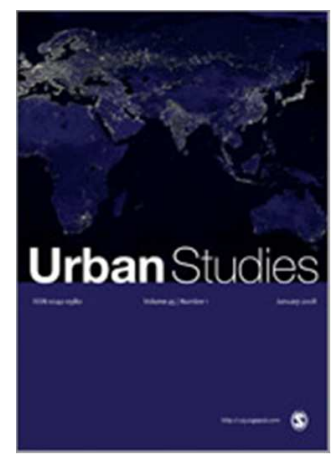

\title{
Beyond sweat equity: Community organising beyond the Third Way
}

\begin{tabular}{|c|c|}
\hline Journal: & Urban Studies \\
\hline Manuscript ID & CUS-167-15-02.R2 \\
\hline Manuscript Type: & Special Issue \\
\hline $\begin{array}{r}<\text { b }>\text { Discipline: Please select a } \\
\text { keyword from the following list } \\
\text { that best describes the } \\
\text { discipline used in your paper.: }\end{array}$ & Political Science \\
\hline $\begin{array}{r}\text { World Region: Please select } \\
\text { the region(s) that best reflect } \\
\text { the focus of your paper. } \\
\text { Names of individual countries, } \\
\text { cities \& economic groupings } \\
\text { should appear in the title } \\
\text { where appropriate.: }\end{array}$ & Western Europe \\
\hline $\begin{array}{l}\text { Major Topic: Please identify up } \\
\text { to two topics that best identify } \\
\text { the subject of your article.: }\end{array}$ & Community, Governance \\
\hline $\begin{array}{r}\text { Please supply a further } 5 \\
\text { relevant keywords in the fields } \\
\text { below:: }\end{array}$ & community, urban crisis, participation, Third Way, Gramsci \\
\hline
\end{tabular}

\section{SCHOLARONE \\ Manuscripts}




\title{
Beyond sweat equity: Community organising beyond the Third Way
}

\author{
Abstract \\ This paper explores the ambivalent nature of community organisation as a response to a \\ "crisis of authority" in post-industrial areas subject to urban regeneration. In the discourse \\ of the Third Way, activism has been increasingly discursively framed as "participation", \\ legitimizing a shift in welfare provision from the state onto civil society and a proliferation of \\ private actors. As part of the process, existing local solidarities based on long-term shared \\ interests and histories of conflict with the parts of the state, have been transformed (in \\ theory) into social networks, forms of short-term instrumental co-operation based on \\ consensus. Community activists are brought into contact with what Rose (after Foucault) \\ describes as the "technologies" of power which are deployed to produce governable \\ subjects, co-opting and dividing them from their base communities. However, local \\ participation also provides our most immediate experience of political economy, what \\ Gramsci identifies as a sometimes fierce sense of difference, and the practical, historically- \\ acquired local knowledge, or "good sense" which can form the basis of a challenge to \\ hegemonic thinking. Engaging empirically with local organisers in the East Midlands, I \\ conclude that the potential of this as a source of contestation depends on two dimensions of \\ practice: (i) the development by activists of a critical understanding of how to foster or \\ maintain long-term collective interests, identity and practices within their communities and \\ (ii) maintaining a clear sense of separation from the state which allows power to be \\ confronted.
}

\section{Keywords}

Community organising; urban crisis; Third Way; participation; Gramsci. 


\section{Introduction: Governmentality and crisis in the $21^{\text {st }}$ century city}

This paper explores the tensions between a "smooth" framing of consensus-based participation, and a context of urban crisis which, as Perry also argues in this volume, makes processes of governing, and their failures to empower citizens or deliver equitable development, increasingly visible. When I began researching the practice of community participation in 2008 , my main purpose was to explore its relationship with the political strategy and discourse of the Third Way. I was interested in the efficacy of its attendant theoretical concept "social capital" - defined by Hall (1999:418) as 'networks of sociability, both formal and informal' - as an explanatory concept for the presence or otherwise of social participation, democratic engagement, and economic development. Giddens (1998), for example, shared Putnam's $(1993 ; 1995)$ key thesis that society was in "civic decline" (Giddens 1998:78). 'The renewal of civil society' therefore became a key principle of the Third Way, particularly 'community renewal through harnessing local initiative' (Giddens 1998:79), while parts of the human experience which were formerly perceived as falling outside of economics (education, friendship, even happiness) were harnessed as social capital, a resource which the rational individual could use to maximize their utility in the market (Coleman, 1988; 1990; also Bourdieu and Wacquant, 1992, for a critical account).

Following a collapse in public confidence after the banking crisis of 2008 and the 2009 parliamentary expenses scandal, participation became subject to newer political iterations, with the newly-elected 2010 Conservative-Liberal Democrat coalition government rapidly implementing its own variant of participatory policy, the "Big Society". This seized on a moment of public distrust to target "Big Government" as the problem, ${ }^{1}$ and, arguably, to distract attention from the failures of the financial markets and political pressure to regulate them by promoting a narrative of "austerity". The 
Decentralisation and Localism Bill 2010 was described by then Minister for Communities, Eric Pickles, as no less than 'a new constitutional arrangement', in which personal 'responsibility' replaced any guaranteed local state provision of services. ${ }^{2}$ Underlying these explicitly political shifts in the policy and discourse of participation was the increasing dominance of social network theory (Granovetter and Swedberg, 2001; Castells, 2010; Woolcock and Narayan, 2000). Like Giddens (1990, after Beck, 2002), social network theorists tend to consign forms of long-term shared interest rooted in structure - particularly those based on class, city, nation - to the status of "zombie categories." The objective becomes the transcendence of these old affiliations in favour of behaviour based on multiple loose ties with diverse agencies, relationships which are by contrast instrumental, short term, and rooted in consensus.

This article sets out to critique this consensus-based, ahistorical understanding of the generation of "social capital", and seeks to restore some of the politics of community participation to a "post-democratic" or "post-political" landscape (Swyngedouw, 2005 and Mouffe, 2005 respectively) by exploring the experiences of three urban community organisations in the East Midlands. It follows Hall's (1999) insistence that social capital be considered as a product of a relationship with government, or governance, while exploring some of his concerns about the resulting distributive dimensions of this apparent public good, particularly along generational and class lines, with the working class and young particularly becoming 'disconnected' from civic society (Hall, 1999:455). Placing the focus on the relationship between governance and agency, this article explores Third Way participatory strategies as a form of revisionist neoliberalism which uses elements of the local state to neutralize more oppositional forms of association (Burawoy, 2000; Hart, 2002). It also deploys Foucault's (1983) concept of governmentality to explore the shift to networked governance not as a reduction in government, as sometimes appears, but 'the dispersal of governmental power across 
new sites of action' (Newman, 2005:12) - not the transfer, but the transformation of power (Blakeley, 2010:132). This allows scrutiny of participation's strong normative dimension, the production of new 'governable subjects' (Rose, 1999) through the setting up of divisions between "civil" and "uncivil" participants, and between what Newman (2005:169) describes as a "legitimating identity" and an "oppositional identity."

Perry has noted that under neoliberalism, urban governing processes have indeed become increasingly "flattened", adopting 'elite, entrepreneurial forms of urban partnership ... legitimised by consensus around the nature of the urban problem and potential solutions', embodied in Perry's case by the "Manchester Men", ${ }^{3}$ (see also Blakeley, 2010). However, this paper uses data gathered from fieldwork with the three case studies to show that urban communities' engagement with this dominant econocentric discourse exists in a relationship, and often in profound contradiction, with their collective identities, motivations and practices, constructed as they are by specific histories, and their particular experience and analysis of political economy, usually at neighbourhood level. Currently, this includes the cumulative after-effects of postindustrial restructuring, failed state-led planning projects, and recession, now overlaid by an austerity narrative which has concrete spatial and social manifestations - what MacLeod and McFarlane (2014:857) have described as 'the process of land grab, informalization, revanchism, punitive urbanism, accumulation-by-dispossession ... that erode the nature of "public" space and sociality". I argue that this apparently intensifying process of accumulation has contributed towards what Gramsci calls a 'crisis of authority' (Gramsci, 1971:275-6) - a condition of awareness and distrust of existing forms of power and ideology, which provides room for an assessment of agency, conflict and the production of alternatives from below. The paper uses data gathered to test the thesis that while neoliberal strategies of participation privilege consensus, this 'crisis of 
authority' in urban governance opens up possibilities for a more politicized and oppositional understanding of "social capital".

It will make use particularly of Gramsci's concepts of the "integral state" and "good sense" (Gramsci, 1971) to explore the ways in which elements of both force and persuasion are brought to bear on theoretically free civil society actors, placing parameters on participation and the generation of "social capital", and how this is contested by specific communities. The local state is therefore seen as a significant 'terrain of the conjunctural' (Gramsci, 1971:178), a site in which dominant political imperatives fight for legitimacy with everyday practices. It concludes that all three groups struggled with a dilemma: while their own "social capital" was founded on an oppositional identity, based on shared critical practice, and a space of difference from the state, this was fundamentally at odds with the consensus model, which is increasingly a requirement of "legitimate" or state-approved participation.

\section{Place, political economy and the "crisis of authority"}

The findings of this research are based on fieldwork, from 2009 to 2012, with three community action groups: two in inner city Nottingham (The Lenton Centre, or TLC, and Sneinton Alchemy), and one in North Nottinghamshire (North Notts Community Arena, or NNCA, in Worksop). Two of these (TLC and NNCA) were running combined leisure and community services formerly closed by the local authority, and arose from fierce campaigns to keep them open, while Sneinton Alchemy was developing a role as a focus for community organising, and had originated in a project to develop local economies supported by UK Think Tank, the New Economics Foundation. ${ }^{4}$ Data was gathered via political ethnographic methods (Watkins, 2013) over an eighteen month period, incorporating elements of immersion to capture informal daily interactions, plus more 
traditional participant observation to capture more formal decision-making processes. It was supplemented by twenty-one semi-structured interviews with members of the boards, staff, volunteers and users of community enterprises (as well as six interviews with selected representatives of key public authorities and Third Sector bodies), allowing data to be gathered on the particular triggers which prompted individuals to participate, their histories, perceptions and aspirations. Of the main interviewees, twelve were male and nine female; twenty were white, and two were black or Asian (both from TLC); and twenty were between 30 and 50 years of age, with two between 20 and 30 . The majority, therefore, were white and of middle age, although there were interesting perspectives gathered from BME or younger activists, particularly in Lenton, and from others who participated in the observational elements.

Amin (2002, 2005), DeFillipis, Fisher and Shragge (2006, 2009), and Cornwall and Coelho (2006), have all made the case for adopting a political economy approach when studying community initiatives, setting any analysis 'within the histories of state-society relations that have shaped the configurations and contestations of the present' (Cornwall and Coelho, 2006:22). Amin (2005) suggests that this offers a way out of the moral narrative which distinguishes between "good" communities (those who generate the right amount, and right kind, of social capital) and "bad" communities (those who don't), focusing instead on the relations which influence who feels they have a right and a motivation to participate, and who doesn't. This requires an exploration of 'how community takes on different meanings in different conditions of economic and social well-being and in different institutional settings' (Amin, 2005:623), while regeneration areas are treated as 'spaces of plural publics, contested claims, and irreconcilable understandings of the good life.' (Amin, 2005:626-627).' This analysis therefore initially considers all three cases of local participation in a specific relationship with political 
economy, in order to understand both the basis of their collective action, and their trajectory in dealing with dominant discourses of governance.

The first, Lenton, was characterised by profound physical and social disjunctures between low income residents in the 1960 s social housing (sometimes known locally in derogatory fashion as the "Crack flats"), and wealthy residents behind the literal cliff walls of "The Park". There were also divisions between the permanent community and the $70 \%$ of the population which was now students, a product of a radical shift from textile manufacture to a knowledge economy, with many formerly family homes being let out as student accommodation. This fractured physical and social environment, described to me as 'bodged up', was seen as the result of optimistic 1960 s social planning which was then neglected:

the way that you move from terraced streets, to the high rise, to the dreadful precinct, the industrial units underneath, the 1970 s housing ... how that relates to everything around it, the busy roads that sort of hem that area in on three sides, but the fourth side is the almost impregnable wall of the Park Estate ... is an example of dreadful town planning really ... (David, 28 July 2010).

However, in spite of sometimes profound divisions based on class, ethnicity, social mobility and geography, a sense of collective identity and agency had been built around the Lenton Community Association (LCA), many of whom had connections to local churches (mostly Christian), the local Labour Party, or were public sector workers. This association, demonstrating the political and cultural roots of "social capital" in the area, was galvanized into more oppositional activity when in 2004, Nottingham City Council made the decision to close a family pool within the LCA's building. This was experienced sharply by the community as a loss to an already deprived area, and the Action Group which campaigned to preserve it drew strong participation from within the community. Ultimately, the LCA reformed itself into a Community Development Trust which negotiated the purchase of the facility from the Council for $£ 10$ under the then-new asset transfer programme. It was re-opened in 2008 as The Lenton Centre, seen specifically 
as providing somewhere the divided elements of the community could be 'physically present in the same place ... a bridge between communities which have very very little in common,' (David, 28 July 2010), a way to 'normalise relationships' through interaction (Adam, 18 August 2009). While TLC therefore almost archetypally modelled a move from conflict to consensus, it retained a fundamental principle of reclaiming publiclyowned social space both from the local state and from potential privatization, which defined its participation.

The second case, in Worksop, demonstrated a more strongly oppositional identity, rooted in a deep sense of geographical and political separation. Located in the very north of Nottinghamshire, NNCA is based in an area of post-coalfield reconstruction, with the overt conflict of the Miner's strike of 1984/85 continuing to figure strongly in collective memory, and with the industry itself still being literally expunged from the landscape. ${ }^{5}$ The NNCA was, like TLC, established in response to a withdrawal of a valued local authority-run service, after Bassetlaw District Council (BDC) in 2002 proposed the closure of the old Bassetlaw Leisure Centre, housed in had been the Raleigh Carlton cycle factory. A steering committee was organised to keep the centre open, finally becoming a community company in 2007, with upgrade work to the building funded by the Coalfields Regeneration Agency. This action group identified itself simply as working class, part of a tradition of self-help (including Trade Unionism and workers' welfare organisations) which arose from expecting nothing from anyone without a fight: 'In ... deprived areas you have to fight for yourself, don't you? You don't get things given you ... the working class community are the ones that stick together, and that fight for each other. Always have done, always will do. And I think that's what this is.' (Tony, 30 April 2010). Although in some ways similar to TLC, social capital at NNCA was therefore deeply rooted in class politics and struggles with the state - the confrontation with BDC being fondly remembered as an occasion of 'feet stamping' and 'chandeliers shaking' (Ian, 27 July 2009). 
The final case, in Sneinton, to the immediate East of Nottingham centre, was socially heterogeneous, accustomed to integrating with migrant communities over many decades, and fiercely autonomous, being deeply suspicious of the state-led planning which had been imposed on neighbouring St Ann's. This wholesale reconstruction of housing in the 1960s, which had steamrollered community concerns along with their homes, was seen as a historic moment which marked an end locally to a respect for authority and trust in stateled development: 'There was no utopia.' (Johns, 2002:225). While Sneinton has a long history of community action, Sneinton Alchemy itself emerged in 2008 from a pilot project supported by the New Economics Foundation and EMDA (East Midlands Development Agency), designed to regenerate local economies and support community development (see North et al, 2007). As in Lenton, the source and nature of its collective identity and agency was complex, cutting across class, but rooted in a sense of 'outsider' status, and the defence of territory and history from what were seen as the impositions of the local state; one participant described it as "outlaw country". It is no coincidence that the community had adopted the figure of William "Bendigo" Thompson as a local hero, a nineteenth century bare knuckle boxer who fought his way out of poverty, described to me as a symbol for 'standing up for yourself' (Jack, 10 March 2011).

The source of these collective identifications therefore gave each what Harvey (1996:19ff) and Williams (1989:249) might identify as their "militant particularisms", 6 forming their core sense of motivation, and the key resource on which they could draw. In social movement terms, Nilsen and Cox (2013:66) call this a 'local rationality', a more abstract sense of separation from the dominant discourse, providing a space from which to critique it. Their concrete experiences of specific political and economic reconstructions, often deeply traumatic, meant that they tended to approach participation from a position not of trust, but of active mistrust. These local rationalities 
were not just historical and spatial, but more recently political, born out of frustration with attempts to engage with the nominally participatory regeneration schemes of Third Way politics, such as the New Deal for Communities, ${ }^{7}$ Surestart, and Pathfinder regeneration projects. These were seen by participants as actively disempowering and stigmatizing those labeled as "deprived", ${ }^{8}$ and representing particular interests which turned them from collaborations into power struggles. Meanwhile, formal democratic processes, both local and national, were seen as increasingly empty and technocratic, with the ideological hollowing out of old "left/right" distinctions leading to the declining legitimacy of traditionally dominant Labour politics: 'You couldn't get a cigarette wrapper between them' (Tony, 5 February 2010).

For all three groups then, social capital was rooted in some degree in an oppositional relation to the state, some more militant than others. This comprised a historic sense of loss, dispossession and even internal exile, ${ }^{9}$ compounded by the disappointment, frustration and unmet demands of Third Way participative schemes. This widening gap between elite constructions and grassroots experiences of participation points towards the 'crisis of governing' outlined by Perry, but also, seen from below, creates what Gramsci describes as a 'crisis of authority' (Gramsci, 1971:275-6), an ongoing moment of departure from old forms of politics:

the great masses have become detached from their traditional ideologies, and no longer believe what they used to believe previously ... The crisis consists precisely in the fact that the old is dying and the new cannot be born; in this interregnum a great variety of morbid symptoms appear ... The death of the old ideologies takes the form of skepticism with regard to all theories and general formulae; of application to the pure economic fact (earnings, etc), and to a form of politics which is not simply realistic in fact ... but which is cynical in its immediate manifestation. (Gramsci, 1971:276).

It was this cynicism, often found in the expression that participatory schemes gave only

'lip service' to devolution of power (Ian, 14 August 2009; Amanda, 3 February 2011), which tended to turn community activists back towards a preference for what Scott 
(1999:282) calls 'street-level trust', an alternative form of social capital which is rooted in shared historical experience, and operates at least partially outside of the state. In Gramscian terms, this can be seen as 'good sense' - a practical, empirical understanding, acquired through history and experience, and rooted in a sense of misalignment with dominant forces. It contains an implicit critique of both "common sense" (incoherent sets of assumptions and common beliefs which characterize any society) and the philosophy of the intellectuals' (Gramsci 1971:331) - the systematized ideas which shape the limits of what we consider to be possible, and is for Gramsci the basis for new forms of political agency:

The unity of theory and practice is ... a part of the historical process, whose elementary and primitive phase is to be found in the sense of being "different" and "apart", in an instinctive feeling of independence, and which progresses to the level of real possession of a single and coherent conception of the world. (Gramsci 1971:333)

In community activism, this sense of independence was palpable, and far from primitive, expressed in practices which emerge directly from their local experience of political economy: respectively, a championing of shared public space and public service, in the face of problematic privatizations; an assertion of class identity and agency in the face of economic neglect and political conflict; and a commitment to "grassroots" horizontal action and accountability, in the face of a mechanistic and controlling local state. The strength of a Gramscian analysis, however, is that it sees civil society participation as part of an "integral state". It focuses attention on how, through the very act of engaging with new networks of governance, apparently strong local rationalities come under pressure from identifiable "technologies of power", reshaping oppositional identities, places and everyday practices in line with the consensus-based model - even where this undermines the basis of social capital for the community itself.

\section{Social capital, governmentality and the technologies of consensus}


For Gramsci, the integral state incorporates both political society and civil society in the construction of consent. This section explores evidence that communities are subject to three key processes which facilitate the shift from independence to consensus: historical (an act of forgetting), spatial (physical reconstruction), and discursive (the adoption of new language and practices). Gramsci calls this "statolatry", the construction of 'a complex and well-articulated civil society, in which the individual can govern himself without his self-government entering into conflict with political society' (Gramsci, 1971:268). However, Foucault's (1983) more all-pervasive concept of governmentality offers a more effective way of understanding how this is achieved, not through overt disciplinary action, but through particular framings of participation, using what Rose (1999:51) refers to as 'technologies for realisation', and what Newman calls 'technologies of power', aimed at 'The fostering of new identities, relationships, expectations and aspirations' (Newman, 2005:11-12) - in this case, social entrepreneurs - 'the good combinards of second modernity' (Davies, 2011:25).

Firstly, community activists found themselves pressurized to forget their collective pasts in the interests of more productive partnerships. This was particularly true of the most overtly working class group in Worksop - precisely those whose social capital Hall (1999) identified as most vulnerable. While NNCA hosted the national $25^{\text {th }}$ anniversary commemoration of the miners' strike, a development professional working for a community alliance on the Manton estate spoke critically of the area's politics, claiming that 'We're still fighting the last miners' strike' and that this contributed towards it being 'a debilitating place to live.' (Daniel, 16 April 2010). The community alliance's practices were based on changing the relationship between residents and the local authority from one which was 'untrusting', 'blaming' and 'adversarial', into one which built 'trust', 'consensus' and 'local consent' (all Daniel, 16 April 2010). This discourse of forgetting was echoed in the District Council, where one officer raised the issue of a lack of trust 
between themselves and NNCA, arguing that 'I don't know if it's down to pride ... or history, but that their language of defiance was evidence of them 'hanging on to the past a bit too much' (Council Officer, 16 April 2010). In Lenton, similarly, a participant told me that in the interests of developing their relationship with the City Council, he had made a deliberate attempt 'to stay out of the politics of it' (Bill, 10 August 2009). This specifically meant leaving behind the conflict around the original closure of the community facility, even though it was this which had fired the community into action originally.

Secondly, at a spatial level, this was mirrored in the construction of new places without history - frameworks for lives newly "liberated" from old forms of collective thinking and shared interest. In Worksop, the economy had been radically reconstructed within thirty years from mining, to huge new distribution centres, drawn by proximity to the M1 and A1, and by a pool of available low-cost labour, much of it on zero and short hours contracts. ${ }^{10}$ New housing estates on the outskirts, the product of the property-building boom of the 1990 s onwards, became home to both more middle class residents moving out of the town, and to new families who commuted back to Sheffield, Doncaster and Nottingham for better-paid work. Manton, the location of the former colliery, had by contrast largely been reduced to one particularly high deprivation estate of 1950 s and 1960s social housing, sandwiched between the town centre to the north, and the golf courses and recreational parkland and forests to the south. This increasing disconnection between wealth and poverty was also seen as a more fundamental divergence in values around collective and mutual obligations. One participant described the new social behaviours in classic neoliberal terms in which retail brands, rather than shared geography or class, provide the key point of identity:

I think there's two communities here. We have the old Worksop people, you know, lived here all their life, who come from the estates, whether it's ... Manton or Kilton or Carlton or Sandy Lane ... it's a very close-knit community, very proud people, and 
passionate about the town ... but ... we've actually got a new population there, that aren't Worksop born and bred, that to all intents and purposes, they just live here. They just live in the house, they don't really come into Worksop I don't think, they'll go to Sainsbury's, they'll go to Tescos, they'll go to B\&Q, but for everything else they can jump in the car and get to Sheffield, or Meadowhall in twenty minutes ....getting the message across to them is always difficult. (Ian, 19 April 2010).

In Sneinton meanwhile, the community had been catalysed by the proposed "Eastside" development, on a substantial area of wasteground known locally as The Island, formerly the site of railway sidings and Boots pharmaceuticals factories. This radical transformation plan on Sneinton's western boundary was seen to have a significant potential impact on Sneinton's largely independent business economy, and was also felt to be a shift in the physical and geographical constitution of Sneinton, potentially changing it from a 'boundary place', its identity rooted in marginality, into one characterised by movement of people through the area and into the City.

Thirdly, at the level of everyday discourse, community participants were under pressure to "professionalise", often a specific requirement of funding bodies. Professionalization was explored as a set of concrete mechanisms of political economy, associated with quite specific practices, notably: (i) the development of a business plan, with income and profit projections based on market research, incorporating a discourse of risk; (ii) the development of an organisational and legal structure, usually increasingly hierarchical, to achieve greater levels of managerial control over spending and to ensure regulatory regimes were being met; and (iii) the recruitment of Trustees with the levels of professional and managerial knowledge to manage these processes. This pressure to adopt a particular form of knowledge and practice was brought into sharp focus with the introduction in 2009 (by the Department for Communities under New Labour) of the Communitybuilders Fund. ${ }^{11}$ The feasibility funding which formed the first phase of the awards was directed entirely towards "professionalization" and the development of their 
infrastructure in order to demonstrate to potential investors that they were "investmentready."

Some participants embraced this, describing it as 'bringing a commercial reality' (Amanda, 13/10/10) to their plans, as a way to secure some recognition from the Council and from development companies ('They'll have to take us seriously,' Amanda, 10 November 2010). However, these processes also gave rise to the most resistance, operating in constant tension with the community activists' shared roots in campaigning, the development of collective practices and forms of ownership, and horizontalism. One participant lamented the way that the arrival of resources and professionalization appeared to link directly to decreasing solidarity and participation, asking: 'Why is it that when you get into a position to help people, you seem to get further away from them?' (John, 20 October 2009), echoing Blakeley's (2010:138) argument about the 'growing gap between those who make a living out of participation ... and grassroots activists'. In one case particularly, the sheer size and nature of the bid revealed conflicts between members over the extent to which they were putting their own interest over the horizontal practice which they valued so highly: 'a philosophical shift from going out to the community to find out about possible uses, and towards an identified business strategy of something like [local quango/development agency]' (Amanda, 27 January 2011); 'We need to be careful not to alienate people who might want to get involved. It's not a business; we don't want to wear suits and ties' (Jack, 27 January 2011). A particular point of contestation for local activists was the pressure to replace local knowledge-sharing with importing the financial and legal knowledge needed to demonstrate "investment-readiness". When pushed, personal social commitment and connection with the grassroots community were repeatedly given a higher value, prioritizing 'the neighbourhood expertise, that exists here' (Amanda, 3 February 2011), and the ability to practice collectively: 'it's not simply do you have capacity $x, y$ and $z$, 
on your Board, it's actually, how do you work together as a group?' (Rob, 27 January 2011).

All three groups therefore appeared to struggle with technologies of consensus which had several clear effects: (i) they created moral distinctions between "co-operators" and "reactionaries"; (ii) spatially, they exacerbated divisions between low and middle income groups; (iii) discursively, they naturalised a division, and even a degree of conflict, between a diminishing number of active participants (seen as service providers) and nonparticipants (seen as consumers), while internal relationships became increasingly less familial, collective, informal and horizontal, and more hierarchical and disciplinary. All of these constructed something closer to a New Right moral narrative of good active citizens and dependents - effectively "strivers" and "skivers". ${ }^{12}$ This pushing of participants towards a consensus-based but "thin" form of social capital stands in fundamental contradiction with communities' own "good sense" construction, built out of shared space, history and experience. However, it is this very contradiction which opens up a space from which dominant narratives and practices can be questioned and challenged.

\section{"Good sense" versus "consensus": contradictions, crisis and contestation}

Davies (2011) has identified what he argues is an inevitable contradiction between the neoliberal ideology of the 'connectionist project', and the neoliberal political economy of 'roll-forward governmentalisation'; between the promise of self-government offered by participatory democracy, and the control technologies which underpin the construction of participatory governance (Pearce, 2010). Data gathered here appears to support this, setting up a conflict for community activists between two potential constructions of social capital: one rooted in internal relationships and values, and one external, fostered by the state, which carry very different suggestions for the meaning of participation; juggling the 
two was described by one participant as like walking 'a continual tightrope,' (Bill, 20 October 2009).

These contradictory pressures can be summarised in tabular form (Table 1, below). This shows that the dominant consensus-based model, associated with Newman's 'legitimating identity', frames participation as concentrated in the hands of a small number with the "right" skills, qualities, and subjectivities: co-operative with external agents, but within a framework of competition and hierarchy; prepared to be innovative and enterprising, while working hard for low or no financial reward; valuing professional knowledge, and prepared to settle for shallow participation based on providing services to "users". This creates issues for community activists, being in many cases in contradiction with the source of their internal legitimacy - their authority to act on behalf of the community. Often more subjective than legal, this appears to rest precisely on the ability to maintain and articulate a shared history and identity, a distinctive analysis of political economy rooted in local knowledge, and the championing of long-term collective shared interests from the "grassroots", through a learned capacity for self-advocacy in the face of the local state. It is this which is expressed here as a "good sense" construction of social capital.

\section{Table 1 here}

These are not simple distinctions: hierarchies can and do of course emerge within community organisations, but the leadership's internal legitimacy tends to rest with their understanding of the community, not with their acceptability to possible investors and partners. That the consensus-based model is actively in tension with the "good sense" construction which underpins legitimacy in the community is significant, setting up the "contradictory consciousness" (Gramsci, 1971), out of which new possibilities can emerge. 
One of the most expressive symptoms of an ongoing sense of contradiction, mistrust, and separateness, was participants' discomfort with the idea that they might be being constructed as part of the increasing privatisation of public services, exploiting volunteer and low-paid labour, 'sweat equity' (Bill, 10 September 2009) to replace publicly-funded provision. This was not something any group accepted easily. The original Lenton Trustees had engaged them in a period of 'soul-searching' over whether they were effectively taking on the burden of running formerly state-provided services, but without the core public funding (Bill, 13 August 2009). They also felt that this might compromise both their advocacy role in the community and the direct relationship between community and local authority, working to 'undermine the whole issue of people in the area fighting for Council services' (Jim, 1 September 2010). An activist in Sneinton saw this sweat equity as a form of potential exploitation in already low and no wage local economies, providing a mirror image of the dominant narrative:

An area that looks after itself, and provides for itself ... you know, you can cut the funding to [laughs]... and I find it slightly uncomfortable, that the similarity between social enterprise and Big Society, it's things that could possibly be done by the state, being done by private initiative ... I don't know ... I'm worried about it being more exploitative of people, actually. (Rob, 17 January 2011).

These findings appear to support those which can be drawn out from earlier case studies of public participation in governance (for example Barnes, Newman and Sullivan, 2007) in suggesting that, contrary to the dominant narrative of participatory governance, two qualities in the most robust activist groups stand out as bringing the most satisfactory outcomes to the community: (i) a strong identity-based collective motivation, based in shared experience and reinforced through collective practice (Barnes et al, 2007:46$47 ; 172)$; and (ii) the maintenance of a clear separation from the state or other sponsoring bodies, allowing participants to challenge them, even while engaging with them (Barnes et al, 2007:118,177). The strongest motivations are found to originate in, and draw on, pre- 
existing experiences of organised engagement with political economy, such as trade unionism (see also Blakeley 2010:136), as well as a shared 'experiential identity' which comes from living together in deprivation and exclusion (Barnes et al, 2007:172;177). These two components are presented here as key to a "good sense" understanding of the world, providing both the motivation to confront the state, and a credible alternative analysis with which to do it.

Seen through a Gramscian lens, these points of departure from dominant narratives should not be romanticized, and community activists are found to face powerful incentives to participate on dominant terms, which are themselves rooted in political economy. In Lenton, where divisive physical planning was seen to have created the problem, there was a major incentive to engage in partnership in a new neighbourhood plan. However, this required consent to the proposed demolition of the Lenton flats in 2012 by Nottingham City Council and Nottingham City Homes, neutralizing any potential challenge to processes which excluded and individualized most of the residents, ${ }^{13}$ just as they had in St Ann's in the 1960s. For activists in Worksop, partnership was seen as a way of winning back a role as working class representatives, "a seat at the table" as relative equals and with direct access to decision-making processes. This was something which, particularly for those from Trade Union backgrounds, was felt to have been lost as political culture became increasingly technocratic under neoliberal restructuring. In Sneinton, where their deepest suspicion was of the "paternalism" and micro-management associated with a secure Labour City Council, partnership was seen as opening up possibilities for securing a new degree of accountability and responsiveness from the local state. Motta and Mansell (2013) have identified this as a classic Third Way strategy, offering incorporation to a "representative" elite, but at a potential cost: increasing detachment from its base in the community and therefore its main source of internal strength, a legitimacy based on difference and shared experience. 
However, the dimensions of "good sense", understood more systematically, do point towards a future research agenda, and a pedagogy, which might help to both understand and strengthen the construction of social capital from below. It is no coincidence, perhaps, that some of the strongest forms of resistance to state-led regeneration narratives are currently found in the anti-gentrification movements, where an intensifying process of accumulation at its most basic level, turning social housing into high-profit development, is being experienced collectively as physical exile and 'social cleansing' (Lees, 2014; also Durose and Lowndes, 2010:354), as well as distrust of local authority. Effectively, then, it is this sense of both internal legitimacy, and difference, which gives groups the confidence to be radical, to avoid being co-opted back into the mainstream as part of a "shadow state", increasingly resembling what they were seeking to change. ${ }^{14}$

\section{Conclusion: High hopes and the practice of local participation}

"The world in't never gonna be perfect, is it?" High Hopes, dir. Mike Leigh, 1988.

This paper has used empirical data from community participants to explore the tensions between a "smooth", consensus-based model of social capital, characteristic of neoliberal and "Third Way" governance, and one forged in relation to political economy and distrust of the state, which is at the heart of community activists' motivation and capacity to act. It therefore incorporates some of Hall's (1999) concerns that social capital must be seen as existing in relation with governance, which privileges the former model, but with significant costs to the latter. To this, it has added a Gramscian reading of civil society participation, which has the benefit of seeing it as forged within multiple relationships of power, one in which participants have access to a unique understanding of their political economy, and the way it has shaped them, both creating and undermining a sense of shared interest. These studies reveal a constant skirmish between a grassroots construction of social capital, 
rooted in distrust of the state and in "fighting for yourself", and the discursive framing of the Third Way - in particular, a series of struggles with specific "technologies of consensus" which have the effect of separating participating groups from the sources of their legitimacy with the wider community. The seductions of co-optation or trasformismo, Gramsci's term for the absorption of opposition leaders into the integral state, are always present, suggesting, as Davies (2011) has, that those engaging with participatory networks need to be prepared to have an 'exit-action' strategy, moving 'outside and against' the state. However, this paper has argued that this outcome is not determined; the contradictions between dominant accounts and actual lived experience, intensified under austerity, create the conditions for a crisis of authority, opening up the possibility of alternative constructions of participation which celebrate the human, the public, the collective and the grassroots. It also suggests that those with a strong experiential identity and local rationality are better placed to engage with participatory governance from a strong base, shaping and using the new spaces of governance laid out by Perry in this volume while challenging and renegotiating the terms of engagement in the process.

The local has to be approached as a contradictory space of engagement, a site of resistance and complicity, collective interest and social discipline. However, a Gramscian framework for research (see Morton, 2007) helps to account for that contingency by focussing on the conditions of political economy which produce forms of affiliation in particular places; the forms these affiliations take; and the way that their ideas and practices work in attrition with the new forms of governance which frame them. The resulting shared local rationality, an understanding of the contingencies of political and economic life revealed at an immediate spatial scale, appears to represent a key source of resistance to technocratic, "thin" participatory regimes of neoliberalism. This suggests that "social capital", seen as an ability to co-operate within the dominant political discourse, is of rather less value to community activists than "social capital" seen as "good sense", a critical collective 
understanding and practice which allows them to separate from and challenge the local state, possibly even providing a starting point for the practice of a broader sense of contestation - asserting a 'right to the city' (Harvey, 2008).

Like Perry's exploration of the potential of more diverse governing practices, studying the formation of political agency is a politics of hope, looking for 'compassionate urbanisms' (MacLeod and McFarlane, 2014:863). Few of the participants I interviewed saw themselves as doing anything as ambitious as building a new politics, but as Gramsci argued, not all 'movements of revolt' are 'one hundred per cent conscious ... governed by plans worked out in advance to the last detail or in line with abstract theory ... reality produces a wealth of the most bizarre combinations.' (Gramsci, 1971:200). For some, however, the politics of this was explicit; locality was somewhere where they could recover a sense of agency, contributing to economic and social regeneration, but in a way which changed the relationship between people and the state, and existing definitions of politics, as they went:

Being an anarchist/an Alchemist [laughs] ... [Me: Can you be both?] Yeah! Can't but. You have to be everything ... There's a need for what we do. I'd love to be a protagonist for solving those needs ... And I would love for us to secure the regeneration [of Sneinton], that's rebuilt organically by the people that live here, as much as it fell into disrepair by processes from outside. (Amanda, 3 February 2011).

There is a pedagogical and reflexive element to this process for agents, if the local is not to be a reactionary space, naturally protectionist and replacing old hierarchies with new. The key dimensions of "good sense" - a collective understanding and experience of political economy, and a clear space of difference from the state and its discursive "technologies" are therefore suggested here not only as the basis of a theoretical critique of the consensusbased model of social capital, but also as a form of 'public sociology' (Bourdieu, 1992). By taking a critical approach to policy, we can perhaps produce findings of some benefit to those at the grassroots who need "social capital" to mean more than simply repairing the effects of state and market failure. 


\section{Acknowledgements}

My thanks go to the community workers of The Lenton Centre, the North Notts Community

Arena, and Sneinton Alchemy, for their co-operation, honesty and hospitality in the

production of this research, and to my PhD supervisors, Professor Paul Heywood, and Dr

Sara Motta, for their academic advice and support.

\section{Notes}

\footnotetext{
${ }^{1}$ Cabinet Office, 18 May 2010: http://www.cabinetoffice.gov.uk/newsroom/news releases/2010/100518-newsbig-society-launch.aspx

${ }^{2}$ The Today Programme, BBC Radio 4, 13 December 2010.

${ }^{3}$ See Blakeley (2010) for an analysis of the populist city patriotism of "Team Manchester" - what Gramsci might call the "city popular".

${ }^{4}$ NEF 2010, http://www.pluggingtheleaks.org/communities taking action/in the uk.htm

${ }^{5}$ Welbeck Colliery, near Meden Vale, ceased production in May 2010, the surface plant being demolished during 2011. BBC 2011, http://www.bbc.co.uk/news/uk-england-nottinghamshire-12918958. Thoresby, the last pit in Nottinghamshire, closed July 2015. BBC 2015, http://www.bbc.co.uk/news/uk-england-nottinghamshire33409746. Kellingley in North Yorkshire, the UK's last deep pit, closed December 2015. BBC, 2015, http://www.bbc.co.uk/news/magazine-33959137.
}

6 "Militant particularism" denotes a struggle which is rooted in a particular place, often traditionally around a dominant industry and class-based, but which has the potential to resonate with broader struggles at national and international scales.

${ }^{7}$ The NDC (Neighbourhood Development Company) for Radford and Hyson Green, a $f 55$ million investment programme which ran from 2001-2010, was the subject of widespread disillusionment over what were seen as failures to share control with the community. One representative reported: 'we had all these hopes and it sounded right ... [but] it was a platform, but with no power ... We spent the summer fighting, fighting, fighting, fighting'. See also Nottingham Evening Post, 16 October 2009, http://www.thisisnottingham.co.uk/Radford-newreport-says/story-12228436-detail/story.html.

${ }^{8}$ One Worksop participant born in the former mining area of Manton was defensive about the way the stigma of "deprivation" was used by the District Council to draw down regeneration funding: 'It's in certain people's interests for Manton to be the roughest place in town,' (Ian, 27/7/09).

${ }^{9}$ See Walkerdine and Jiminez (2012) on the affective dimensions of subjectivity, belonging, and agency.

${ }^{10}$ Defined by ACAS, the Advisory, Conciliation and Arbitration Service, as 'generally understood to be a employment contract between an employer and a worker, which means the employer is not obliged to provide the worker with any minimum working hours' (ACAS, http://www.acas.org.uk/zerohours). 
${ }^{11}$ The stated objective of Communitybuilders was 'to make sustainable investments in community enterprises to build their long term financial viability and increase their ability to deliver significant social impact in their communities.' See: http://www.communitybuildersfund.org.uk/about-the-fund/

${ }^{12}$ A political discourse which pits "hard-workers" against "welfare dependents", popular with the Cameron Government from 2013 (Valentine and Harris, 2014).

${ }^{13}$ In May 2012, residents were served with eviction notices and instructed to reapply for social housing elsewhere. There were no guarantees that that the site would be used for new social housing, rather than being developed commercially for further student residences.

Nottingham Post, 12 August 2011: http://www.thisisnottingham.co.uk/Don-t-demolish-homes-residentsappeal/story-13120442-detail/story.html

${ }^{14}$ One member of a fuel poverty group with just such a strong shared analysis was cited by Barnes et al (2007:177) as saying: 'We have no taboos. We are not worried about anything, we don't care who we upset.' 


\section{References}

Amin A, Cameron A and Hudson R (2002) Placing the Social Economy. London and New York: Routledge.

Amin A (2005) Local Community on Trial, Economy and Society, 34/4:612-633.

Barnes M, Newman J and Sullivan H. (2007) Power, Participation and Political Renewal: Case Studies in Public Participation. Bristol: Policy Press.

Beck U (2002) Zombie Categories: Interview with Ulrich Beck, in U Beck \& E Gernsheim, Individualization: Institutionalized Individualism and its Social and Political Consequences. London: Sage.

Blakeley G (2010) Governing Ourselves: Citizen Participation and Governance in Barcelona and Manchester, International Journal of Urban and Regional Research, 34/1:130-145.

Bourdieu P and Wacquant LJD (1992) An Invitation to Reflexive Sociology. Cambridge: Polity.

Castells M (2010) The Rise of the Network Society. $2^{\text {nd }}$ ed. Oxford: Wiley-Blackwell. Coleman JS (1988) Social Capital in the Creation of Human Capital, American Journal of Sociology, 94/Supplement: S95-S120.

Coleman JS (1990) Foundations of Social Theory. Cambridge, Ma; London: Harvard University Press.

Cornwall A and Coehlho VSP (eds.) (2006) Spaces for Change? The politics of citizen participation in new democratic areas. London; New York: Zed Books.

Davies JS (2011) Challenging Governance Theory: from networks to hegemony. Bristol: Policy Press.

DeFillippis J, Fisher R and Shragge E. (2006) Neither Romance Nor Regulation: Reevaluating Community, International Journal of Urban and Regional Research, 30/3:673-689.

DeFillippis J, Fisher R and Shragge E (2009) What's Left in the Community? Oppositional Politics in Contemporary Practice, Community Development Journal, 44/1:38-52. 
Department for Communities and Local Government (2010) Decentralisation and The Localism Bill: an essential guide. London: Department for Communities and Local Government.

Durose C and Lowndes V (2010) Neighbourhood governance: Contested Rationales Within a Multi-Level Setting - A Study of Manchester, Local Government Studies, 36/3: 341-359.

Foucault M (1983) The Subject and Power, in HL Dreyfus and P Rabinow (eds.), Michel Foucault: Beyond Structuralism and Hermeneutics, $2^{\text {nd }}$ ed. Chicago: University of Chicago Press.

Giddens A (1998) The Third Way: The Renewal of Social Democracy. Cambridge: Polity Press.

Giddens A (1990) The Consequences of Modernity. Cambridge: Polity Press.

Gramsci A (1971) Selections from the Prison Notebooks. London: Lawrence and Wishart.

Granovetter M and Swedberg R (eds.) (2001) The Sociology of Economic Life. $2^{\text {nd }}$ ed. Oxford: Westview Press

Hall, P A (1999) Social Capital in Britain. British Journal of Political Science, 29/3: 417-461.

Hart G (2002) Disabling Globalization: Places of power in Post-apartheid South Africa. Berkeley: University of California Press.

Harvey D (1996) Justice, Nature and the Geography of Difference. Oxford: Blackwell. Harvey D (2008) The Right to the City, New Left Review, 53:23-40.

Johns RI (2002) St Ann's Nottingham: Inner-City Voices. Warwick: Plowright Press. Lees L (2014) The Urban Injustices of New Labour's "New Urban Renewal": the Case of the Aylesbury Estate in London, Antipode, 46/4:921-947.

MacLeod G and McFarlane C (2014) Introduction: Grammars of Urban Injustice, Antipode, 46/4:857-873.

Morton A (2007) Unravelling Gramsci: Hegemony or Passive Revolution in the Global Political Economy. London: Pluto. 
Motta SC and Mansell J (2013) Re-articulating Dissent: Representing the Working Class from Third Way to New Right in Britain and Chile, Political Studies, 61/4:748-766.

Mouffe C (2005) On the Political. London: Routledge.

Newman J (ed.) (2005) Remaking Governance: Peoples, Politics and the Public Sphere. Bristol: Policy Press.

Nilsen HG and Cox L (2013) What Would a Marxist Theory of Social Movements Look Like?, in C Barker et al (eds.) Marxism and Social Movements. Leiden; Boston: Brill.

North D, et al (2007) Interventions to Tackle the Needs of Deprived Areas: analysis of six policy case studies. York: Joseph Rowntree Foundation.

Pearce J (ed.) (2010) Participation and Democracy in the Twenty-First Century City. Basingstoke: Palgrave Macmillan.

Perry B (2013) Governing Crises and Crises of Governing: Collaboration, Capitulation or Capture? In: Interrogating Urban Crisis: Governance, Contestation and Critique, De Montfort University 9-11 September 2013.

Putnam RD (1993) Making Democracy Work: Civic Traditions in Modern Italy. Princeton, N.J.: Princeton University Press.

Putnam RD (1995) Bowling Alone: America's Declining Social Capital, Journal of Democracy, 6/1:65-78.

Rose N (1999) Powers of Freedom: Reframing Political Thought. Cambridge: Cambridge University Press.

Rowson J, Broome S and Jones A (2010) Connected Communities: How Networks Power and Sustain the Big Society. London: RSA.

Scott J (1992) Domination and the Arts of Resistance: Hidden Transcripts. New ed. New haven; London: Yale University Press.

Scott J (1999) Geographies of Trust, Geographies of Hierarchy, in Warren M (ed.) Democracy and Trust. Cambridge: Cambridge University Press. PP.273-289.

Swyngedouw E (2005) Governance Innovation and the Citizen: the Janus Face of Governance-beyond-the-State, Urban Studies, 42/11: 1991-2006.

Valentine G and Harris C (2014) Strivers vs skivers: Class prejudice and the demonisation of dependency in everyday life, Geoforum, 53:84-92. 
Walkerdine V and Jiminez L (2012) Gender, Work and Community After Deindustrialisation: a Psychosocial Approach to Affect. [E-book]. Palgrave Macmillan.

Watkins H (2013) A Theoretical and Methodological Approach to the Politics of Community: the Application of Political Ethnography, Enquire, 6/1: 39-59.

Williams R (1989) Resources of Hope: Culture, democracy, socialism. London: Verso.

Woolcock M and Narayan D. (2000) Social Capital: Implications for Development Theory, Research and Policy, World Bank Research Observer, 15/2: 225-249. 
1

2

3

4

5

6

7

8

9

10

11

12

13

14

15

16

17

18

19

20

21

22

23

24

25

26

27

28

29

30

31

32

33

34

35

36

37

38

39

40

41

42

43

44

45

46

47

48

49

50

51

52

53

54

55

56

57

58

59

60

Table 1. Good sense versus consensus-based forms of social capital

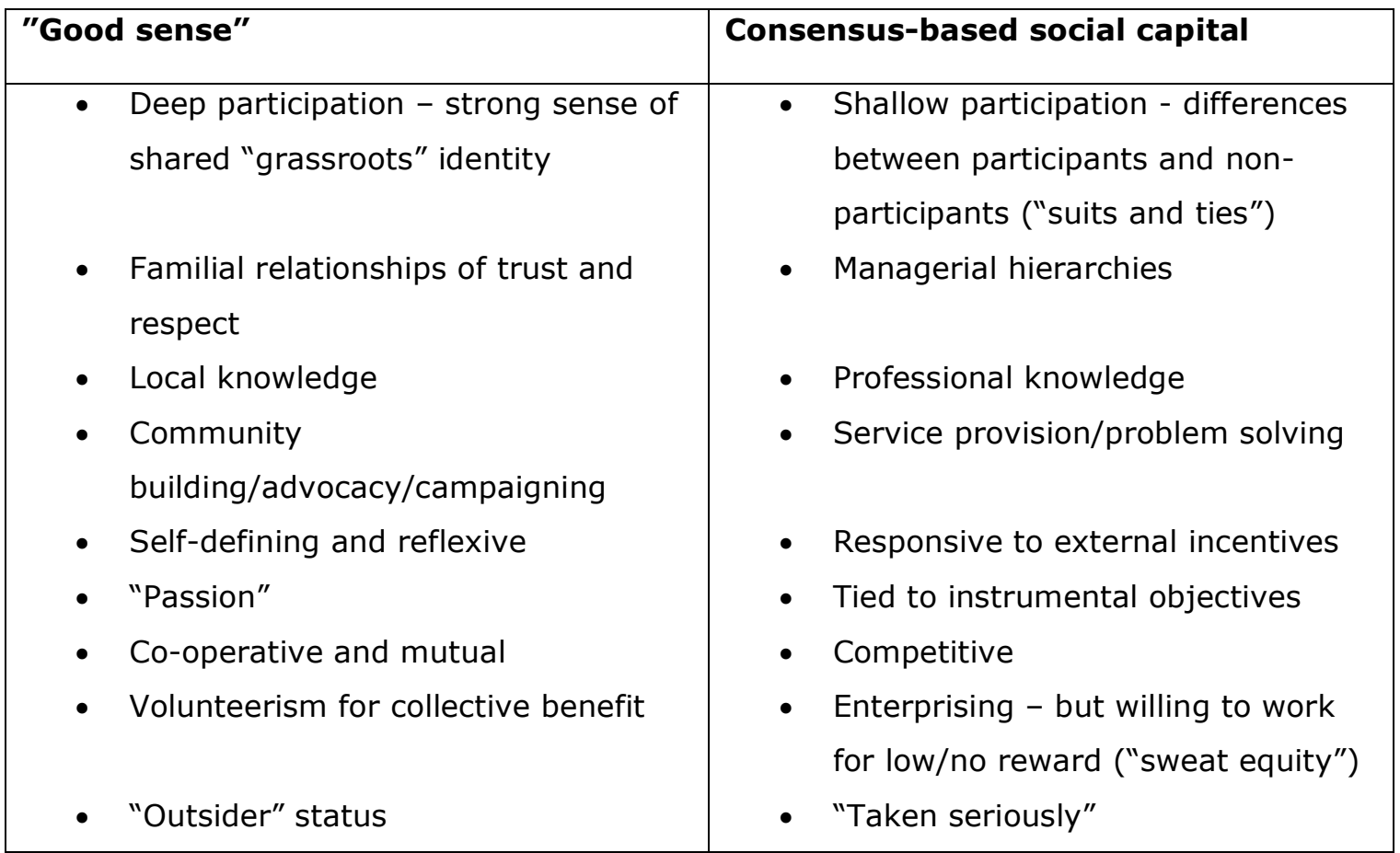

